IZABELA KRASIŃSKA* - KIELCE

\title{
DZIALALNOŚĆ WYDAWNICZA ZWIĄZKU KSIĘŻY ABSTYNENTÓW (1903-1914)
}

\section{Wstęp}

Związek Księży Abstynentów był jedną z wiodących polskich organizacji abstynenckich powstałych w okresie zaborów. Od początku istnienia (13 września 1902 r.) czołową postacią organizacji, zrzeszającej duchowieństwo katolickie był ks. Kazimierz Niesiołowski, długoletni proboszcz parafii w Pleszewie'. W omawianym okresie Związek Księży Abstynentów funkcjonował na terenie archidiecezji gnieźnieńskiej i poznańskiej, lwowskiej oraz diecezji chełmińskiej, tarnowskiej i przemyskiej.

Celem Związku Księży Abstynentów było zwalczanie alkoholizmu. Zadanie to realizowano poprzez pozyskiwanie dla organizacji jak najszerszych kręgów duchowieństwa, zwalczanie pijaństwa i zgubnych zwyczajów spożywania napojów alkoholowych, popieranie działalności innych towarzystw abstynenckich i kościelnych bractw wstrzemięźliwości, lecznic dla alkoholików, bezalkoholowych jadłodajni, herbaciarni, gospód wstrzemięźliwości. Podstawowym celem było uświadamianie szerokich warstw społeczeństwa, o zgubnym wpływie alkoholu na organizm, poprzez urządzanie wykładów, pogadanek i prelekcji, wystaw a także publikowanie stosownej literatury². I właśnie działalność wydawnicza Związku Księży Abstynentów stanowi przedmiot niniejszego artykułu.

* Izabela Krasińska - dr historii, adiunkt w Instytucie Dziennikarstwa i Informacji Uniwersytetu Jana Kochanowskiego w Kielcach, e-mail: izabela.krasinska@ujk.edu.pl

${ }^{1}$ Kazimierz Niesiołowski (1872-1949) - kapłan katolicki i działacz społeczny, od 1902 r. prezes Związku Księży Abstynentów na archidiecezję gnieźnieńską i poznańską, prałat Jego Świątobliwości papieża Piusa XI, honorowy obywatel Pleszewa. Zob. M.P. Romaniuk, Ksiądz Kazimierz Niesiołowski (1872-1949), w: W trosce o trzeźwość Narodu. Sylwetki najwybitniejszych działaczy trzeźwościowych XIX i XX wieku oraz antologia ich pism, praca zbiorowa, [red. M. P. Romaniuk], t. 2, [Warszawa 1996], s. 265, 267-268.

${ }^{2}$ Ustawy Zwiazku Księży Abstynentów, Poznań 1902, s. b.p.; Szerzej na temat działalności Związku Księży Abstynentów zob.: I. Krasińska, ,,Przez abstynencję kapłanów do wstrzemięźliwości ludu”. Związek Księży Abstynentów (1902-1914) (w druku). 


\section{Książki i broszury}

W 1903 r. nakładem Związku Księży Abstynentów ukazała się broszura kolędowa Odezwa do matek $w$ ważnej sprawie, sygnowana kryptonimem X.*. Jej autorstwo przypisywano ks. Kazimierzowi Niesiołowskiemu lub Antoniemu Cyrylowi Królickiemu ${ }^{3}$, który używał podobnego kryptonimu ${ }^{4}$. Wydrukowano ją w Pleszewie w drukarni F.K. Ziółkowskiego i Sp. Ta objętościowo niewielka, bo licząca zaledwie 31 stron tekstu książeczka, ukazała się w łącznym nakładzie 10300 egzemplarzy ${ }^{5}$. Częściowo udało się ją sprzedać, ale w głównej mierze została rozdana kobietom podczas wizyt kolędowych, składanych wiernym na terenie archidiecezji gnieźnieńskiej i poznańskiej w grudniu 1903 r. i styczniu 1904 r. ${ }^{6}$

Celem wspomnianej broszury było zwrócenie uwagi matkom, na negatywne skutki spożywania przez nie i ich dzieci, napojów alkoholowych. Kobiety zwykle doświadczały najwięcej zła płynącego z nadmiernego spożywania alkoholu przez ich mężów, którzy niejednokrotnie wydawali na niego całe wynagrodzenie, a wracając do domów wszczynali bójki i awantury. Bez wódki, wina, piwa nie mogła odbyć się żadna uroczystość rodzinna, np. wesele, chrzciny, a nawet stypa pogrzebowa: „A więc, [...] trzeba pić, choć bieda, trzeba pić, choć żona łzy leje, trzeba pić, choć w domu dla zgłodniałych dzieci kawałka chleba nie ma"’.

Dalej pisze ks. K. Niesiołowski o najmłodszych, którym do szczęśliwego dzieciństwa nie potrzebne są drogie zabawki, lecz spokój panujący w domu i radośni rodzice. Ostrzega, aby pod żadnym pozorem nie częstować, zachęcać czy zmuszać dzieci do spożywania napojów alkoholowych, wierząc na przykład w ich lecznicze właściwości. Bowiem: „Ani wino, ani piwo, ani wódka, ani żaden napój upajający dziecku sił żadną miarą nie doda. - Mleko, mączne pokarmy, jajka, owoce: oto prawdziwie pożyteczne i wzmacniające dla dzieci napoje i pokarmy"s. Napoje alkoholowe spożywane przez dzieci nie prowadzą do zdrowia, a przeciwnie mogą się stać przyczyną śmierci, kalectwa oraz wielu chorób, takich m.in. jak: epilepsja, czy choroba św. Wita zwana również pląsawicą. Dlatego: „O ile to jest w naszej mocy, postaramy się o to, aby nigdy kropla alkoholu nie przeszła przez

${ }^{3}$ Antoni Cyryl Królicki (1836-1900) - kapłan katolicki, teolog ascetyczny, profesor filozofii w Akademii Duchownej w Petersburgu, doskonały kaznodzieja. Wiele ze swych kazań ogłosił drukiem, jako oddzielne publikacje. Zob. H.E. Wyczawski, Królicki (Krulicki) Antoni Cyryl, w: Stownik polskich teologów katolickich (dalej: SPTK), t. 2, red. H.E. Wyczawski, Warszawa 1982, s. 439.

${ }^{4}$ Ks. Antoni Królicki używał kryptonimu X* zob. NUKAT - katalog centralny zbiorów polskich bibliotek naukowych i akademickich, http://www.nukat.edu.pl/ (dostęp: 8. 04. 2013 r.).

${ }^{5}$ Pierwszy nakład broszury (6 000 egzemplarzy) rozszedł się prawie w całości i dlatego zdecydowano się wydrukować jeszcze dodatkowo 4300 egzemplarzy.

${ }^{6}$ K. Niesiołowski, Związek Księży Abstynentów w Polsce Zach.[odniej] (archidiec.[ezja] gnieźnieńska i poznańska i diec.[ezja] chetmińska). (1902-1927), w: Polski Zwiąek Księży Abstynentów. Pamiętnik z okazji 25-lecia istnienia, Poznań 1927, s. 13; M. Mrugas, Sprawozdanie ze zebrania „Związku księży abstynentów” odbytego dnia 16. marca br. w Gospodzie wstrzemięźliwości przy Dominikanach w Poznaniu, „Miesięcznik dla Popierania Ruchu Wstrzemięźliwości”, 5 (1905) s. 69.

${ }^{7}$ [K. Niesiołowski], Odezwa do matek w ważnej sprawie, Pleszew 1903, s. 6.

${ }^{8}$ Tamże, s. 13. 
usta dzieci naszych"9. Ks. K. Niesiołowski zwracał uwagę ciężarnym kobietom oraz matkom karmiącym, aby zaprzestały spożywania napojów alkoholowych, gdyż przez krew i mleko matki przenikają one do organizmów płodów oraz niemowląt, mogąc wywołać niepożądane skutki dla ich zdrowia oraz właściwego rozwoju fizycznego i psychicznego ${ }^{10}$.

Rodzicom powinno zależeć na szczęściu swych dzieci i na tym, aby były zdrowe, mądre, dobrze się uczyły oraz wyrosły na uczciwych i szlachetnych ludzi. Aby się to urzeczywistniło nie powinny nigdy spożywać napojów alkoholowych, ani obcować z pijanymi domownikami. Nie ma bowiem: ,[...] tak brudnej, bydlęcej rozpusty, której by człowiek w stanie pijanym nie był zdolny popełnić! [...]. Alkohol przemienia częstokroć człowieka w istne zwierzę drapieżne. [...] pobudza do wszystkich możliwych grzechów głównych"11. Wszelkie zło wyrządzane zazwyczaj bywa pod wpływem alkoholu. Dalej ks. K. Niesiołowski przytacza przykład pewnego robotnika z Erfurtu, którego skazano na 10 lat więzienia za liczne przewinienia jakich się dopuścił. Winowajca po ogłoszeniu wyroku miał powiedzieć, że najbardziej żałuje, że nie ma na sali sądowej jego dzieci, które by ostrzegł przed gorzałką, gdyż ta „wszystkiemu jest winna”"

Ksiądz K. Niesiołowski apelował do matek, aby nie posyłały dzieci do karczmy, gospody czy restauracji po napoje alkoholowe, gdyż „ciekawskie” z natury najpierw same spróbują tego, co znajduje się w butelce: „Nie posyłajcie dziecka waszego, choćby się małżonek koniecznie tego domagał, choćby się nawet gniewał. Jeżeliby miała burza w domu powstać, już lepiej idźcie same"13.

Na koniec stwierdził, że świadomy jest tego, iż zapewne upłynie jeszcze dużo czasu zanim rodzice zrozumieją, jak wielką krzywdę wyrządzić może dzieciom alkohol. Zachęcał do wytrwałości. Zdawał sobie też sprawę, że wiele matek po przeczytaniu adresowanej do nich książeczki w gniewie wyrzuci ją lub spali wierząc, że same najlepiej wiedzą, co jest dla nich i ich dzieci najlepsze. Apelował jednak, aby nie niszczyć broszury, lecz przekazywać ją innym kobietom, dla których może okazać się wartościową. Najlepszą zdaniem autora zapłatą za macierzyńskie trudy i wyrzeczenia będą słowa, jakie zdrowe i szczęśliwe dzieci wypowiedzą do swych mądrych i kochających matek, które wpajały im zasady wstrzemięźliwości od alkoholu: „Mamo, to nie kieliszek tak mnie cieszy, nie z kieliszkiem mi tak ładnie! Mamo, ty wiesz, co ja najwięcej lubię. Takie wisienki ładne, jabłuszka czerwone, gruszki słodkie, te mi bardzo smakują. [...] wódka drapie i pali języczek, wino kwaśne, piwo znowu gorzkie. Tego, mamo, nie lubię wcale" 14 !

$\mathrm{Z}$ uwagi na fakt, że oba nakłady Odezwy do matek w ważnej sprawie dość szybko się wyczerpały, a duchowni zgłaszali zapotrzebowanie na tego typu druki, już w 1904 r. ukazało się w Pleszewie nakładem Związku Księży Abstynen-

\footnotetext{
${ }^{9}$ Tamże, s. 19.

${ }^{10}$ Tamże, s. 22.

${ }^{11}$ Tamże, s. 22-23.

12 Tamże, s. 24.

13 Tamże, s. 29.

${ }^{14}$ Tamże, s. 31.
} 
tów jej drugie poprawione i rozszerzone wydanie. Wydrukowano ją w oficynie F.K. Ziółkowskiego i Sp. Odezwę tę, podobnie jak poprzednią, napisał ks. Kazimierz Niesiołowski, lecz opatrzył innym tytułem Czytajcie matki. Odezwa do matek $w$ ważnej sprawie. Broszura doskonale nadawała się do rozdania pomiędzy członkinie Bractwa Matek Chrześcijańskich. Jej nakład wyniósł ok. 6000 egzemplarzy i podobnie, jak poprzednia broszura, została prawie w całości rozdana, a częściowo także sprzedawana ${ }^{15}$.

Kolejna publikacja wydana nakładem Związku Księży Abstynentów ukazała się ok. 1906 r., a było nią dziełko autorstwa ks. K. Niesiołowskiego Przyjaciel czy wróg? Książeczka dla ludu polskiego. Licząca 55 stron publikacja, wydrukowana została w Pleszewie w drukarni wspomnianego F.K. Ziółkowskiego i Sp. Nakład wyniósł początkowo 10000 egzemplarzy, lecz z uwagi na duże zainteresowanie dodrukowano dalszych 12000 egzemplarzy ${ }^{16}$. Oba nakłady dość szybko się wyczerpały. Za egzemplarz należało zapłacić 10 fenigów ${ }^{17}$.

W dziełku tym autor rozpatrywał problem alkoholizmu w ujęciu społecznym i psychologicznym. Podzielił się wnioskami z przeprowadzonych przez siebie i innych badań, dotyczących konsumpcji napojów alkoholowych, przedstawił „ku przestrodze" przykłady „z życia wzięte”. Zupełnie niepotrzebnie zdaniem autora: „Ludzie ozdobili alkohol rozmaitymi cnotami, jakich nie posiada, wynieśli go ponad wszystkie przyjemności, wychwalają go wszystkimi językami. Stworzyli sobie cudo, którego ani dotknąć, ani ganić nie pozwolą. Niemiec ukochał piwko, Francuz wino, a Polak swą gorzałkę; biada śmiałkowi któryby ubliżył tym ulubionym napojom"18. Zauważył, że alkohol nikomu nie służy i nikt nie powinien go spożywać, gdyż jest trucizną, nie wzmacnia i nie pożywia, nie gasi pragnienia, wywołuje złudne uczucie ciepła, niszczy zdrowie, prowadzi do ubóstwa, może stać się przyczyną nędzy moralnej, doprowadzić do różnych przewinień, nie wykluczając zbrodni ${ }^{19}$.

W dalszej części książki ks. K. Niesiołowski podzielił się z czytelnikami swymi spostrzeżeniami na temat konsumpcji alkoholu wśród społeczeństwa polskiego. Oszacował np., że na Śląsku i w Księstwie Poznańskim w 1895 r. na jedną osobę przypadało 13 litrów wypitej wódki. Nieco lepiej sytuacja przedstawiała się w Prusach Zachodnich, gdzie pito mniej z uwagi na większe ubóstwo miejscowej ludności ${ }^{20}$.

${ }^{15}$ M. Mrugas, Sprawozdanie ze zebrania, s. 69; Nowi członkowie honorowi „, Wyzwolenia”. II. Ks. Kazimierz Niesiołowski, „Wyzwolenie”, 11 (1912) s. 185.

${ }^{16}$ Nowi członkowie, s. 185. Niektóre źródła podają, że łączny nakład książki mógł osiągnąć liczbę 24000 egzemplarzy. Zob. Niesiołowski, Związek Księży Abstynentów, s. 13.

${ }^{17}$ M. Mrugas, Sprawozdanie z walnego zebrania „Związku księży abstynentów” odbytego dnia 11-go czerwca b.r. na sali Gospody wstrzemięźliwości przy Dominikanach w Poznaniu, „Miesięcznik dla Popierania Ruchu Wstrzemięźliwości”, 44 (1907) s. 107.

${ }^{18}$ K. Niesiołowski, Przyjaciel czy wróg? Książeczka dla ludu polskiego, Pleszew [1906], s. $32-33$.

${ }^{19}$ Tamże, s. 33; A. Gulczyński, Ks. prałat Kazimierz Niesiołowski (1872-1949), Pleszew 1995, s. 40 .

${ }^{20}$ Niesiołowski, Przyjaciel, s. 34. 
Powołał się również na badania przeprowadzone w zakładzie dla psychicznie chorych w Kulparkowie pod Lwowem. Dyrektor tej placówki, Roman Zagórski ${ }^{21}$ oszacował, że w 1902 r. na 570 pacjentów, u 113 napoje alkoholowe stały się główną przyczyną choroby psychicznej, a w 1904 r. na 678 chorych 203 osoby to „obłąkani wskutek pijaństwa"22.

Na koniec ks. K. Niesiołowski zwrócił się do czytelników z prośbą, aby nie pili trunków upajających, nie częstowali i nie zmuszali do picia innych, a także by nie drwili z propagatorów abstynencji. Zachęcał do czytania prasy i książek, zawierających porady, jak zwalczać pijaństwo, a dzięki pożytecznej lekturze, pouczać innych, zwłaszcza dzieci i młodzież o szkodliwości spożywania alkoholu, gdyż: „Stokroć łatwiej [...] zapobiec złemu, aniżeli usuwać je, gdy już raz silne zapuściło korzenie"23.

W 1910 r. w Poznaniu, nakładem Związku Księży Abstynentów ukazała się kolejna publikacja. Była nią książeczka autorstwa szwajcarskiego bpa Augustyna Eggera Duchowieństwo a walka $z$ alkoholizmem ${ }^{24}$. Z języka niemieckiego przetłumaczył ją ks. Nikodem Cieszyńskii ${ }^{25}$. Początkowy nakład dziełka oszacować można na ok. 3000 egzemplarzy ${ }^{26}$, a objętość egzemplarza wynosiła 45 stron. Wydrukowano je w poznańskiej drukarni „Praca”. Pomysłodawcą wydania, przetłumaczonej na język polski broszury był ks. Kazimierz Niesiołowski, który uważał bpa A. Eggera za jednego z najwybitniejszych działaczy trzeźwościowych. Samo zaś dzieło poznał w oryginale jeszcze w latach 90. XIX wieku²7.

Poprzez swe dziełko bp A. Egger propagował zupełną abstynencję od wszelkich napojów alkoholowych, podając niezbędne wskazówki, jak należy ją wprowadzać w czyn. Uważał, że tylko całkowita abstynencja, a nie umiarkowane spożywanie napojów alkoholowych, może doprowadzić człowieka do szczęścia: „Umiarkowanie jest dobre, abstynencja lepsza. Do umiarkowania jesteśmy wszyscy zobowiązani przyrzeczeniem na chrzcie św. danym, do abstynencji nikt. Wybierają ją dobrowolnie ci, którzy zrzucili z siebie kajdany pijaństwa. Ale jeszcze szczęśliwsi, którzy złożyli przyrzeczenie wstrzemię́liwości, nie z własnej potrzeby, tylko w tym celu, by drugich słowem i przykładem ratować od śmierci duchowej" 28 .

${ }^{21}$ Roman Zagórski (1875-1927) - lekarz-psychiatra, członek Polskiego Towarzystwa Psychiatrycznego. Kierował zakładami dla psychicznie chorych w Kobierzynie i Kulparkowie. W. Łuniewski, Ś.P. Dr. Roman Zagórski, „Rocznik Psychiatryczny”, 5 (1927) s. 199-200.

${ }^{22}$ Niesiołowski, Przyjaciel, s. 40.

${ }^{23}$ Tamże, s. 53-55.

${ }^{24}$ Tytuł oryginalny brzmi Der Klerus und die Alkoholfrage.

${ }^{25}$ Nikodem Cieszyński (1886-1942) - kapłan katolicki, kaznodzieja, literat, członek Poznańskiego Towarzystwa Przyjaciół Nauk. Był redaktorem „Roczników Katolickich” i pisma przeznaczonego dla młodzieży uniwersyteckiej „Filareta”. I. Posadzy, Ks. Nikodem Cieszyński. W 25 rocznicę śmierci, „Przewodnik Katolicki” 44 (1967) s. 395-396.

${ }^{26}$ O. Śpikowski, Sprawozdanie z walnego zebrania Związu Księży Abstynentów, „Miesięcznik dla Popierania Ruchu Wstrzemięźliwości”,76 (1910) s. 51.

${ }^{27}$ Gulczyński, Ks. prałat Kazimierz Niesiołowski, s. 37.

${ }^{28}$ A. Egger, Duchowieństwo a walka z alkoholizmem, Poznań 1910, s. 19-20. 
Dzieło swe dedykował wszystkim kapłanom, których nazywał ,żołnierzami Chrystusowymi”, bowiem ich zadaniem było „uszlachetnianie dusz ludzkich”. Na łamach abstynenckiego pisma „Wyzwolenie” dowodzono, że głos bpa A. Eggera: „Jest [...] zbyt poważny i zbyt dużym rozejdzie się echem, [...] aby nie osiągnął zamierzonego celu" ${ }^{29}$ ! Dlatego też wspomniane dziełko rozesłano wszystkim księżom pracującym na terenie archidiecezji gnieźnieńskiej i poznańskiej oraz diecezji chełmińskiej, a także duchowieństwu polskiemu w Ameryce ${ }^{30}$.

Wszystkie wyżej wymienione publikacje ukazały się nakładem Związku Księży Abstynentów na archidiecezję gnieźnieńską i poznańską. Pamiętać należy, że w działalność wydawniczą włączył się też Związek Księży Abstynentów dla Galicji i Bukowiny. Na szczególne wyróżnienie zasługiwał ks. Józef Janiszewski ${ }^{31}$ z Hliboki, o którym wiadomo, że: ,[...] całą duszą był oddany idei abstynenckiej, a że miał zdolności pisarskie, jął słowem i piórem szerzyć zasady zupełnej wstrzemięźliwości wśród swego otoczenia i napisał wiele cennych broszur, wierszy i ulotek abstynenckich, które [...] zasilają nasze biblioteczki parafialne i szkolne"32.

Jedną z tego typu broszur było dziełko Do walki bracia! Pierwsze wydanie ukazało się w Czerniowcach ok. 1910 r., nakładem autora. Nakład musiał się szybko wyczerpać, skoro ok. 1912 r. autor opublikował kolejne wydanie broszury, treściowo znacznie powiększone ${ }^{33}$. Ukazało się ono nakładem Związku Księży Abstynentów dla Galicji i Bukowiny ${ }^{34}$, a wydrukowano je w Miejscu Piastowym, w drukarni Towarzystwa „Powściągliwość i Praca” ${ }^{35}$, którą kierował wówczas

${ }^{29}$ Z bibliografii. „Duchowieństwo a walka z alkoholizmem”, „Wyzwolenie”, 11 (1910) s. 6.

${ }^{30}$ O. Śpikowski, Związek Księży Abstynentów. Walne zebranie Związku Księży Abstynentów, „Świt”, 89 (1911) s. 100.

31 Józef Janiszewski (1880-1940) - kapłan katolicki, pastoralista, działacz abstynencki. Od 1909 r. prezes Związku Księży Abstynentów dla Galicji i Bukowiny. Po odzyskaniu przez Polskę niepodległości objął stanowisko sekretarza generalnego Towarzystwa Zupełnej Wstrzemięźliwości od Napojów Alkoholowych „Wyzwolenie” i Polskiego Związku Księży Abstynentów. W 1921 r. zrezygnował z tych funkcji i odszedł do pracy duszpasterskiej. Zob. M. Banaszak, Janiszewski Józef, SPTK, t. 5, red. L. Grzebień, Warszawa 1983, s. 575-576.

${ }^{32}$ J. Ciemniewski, Związek Księży Abstynentów na Małopolskę (1907-1927), w: Polski Związek Księży Abstynentów, s. 33.

${ }^{33}$ Wydanie pierwsze liczyło 16 stron tekstu, a drugie już 32 strony. Kolejne ukazało się w 1916 r. we Lwowie nakładem Komitetu Wydawnictwa Dziełek Ludowych (110 stron). Ostatnie czwarte wydanie opublikował nieznany bliżej wydawca w Kościanie w 1926 r. Była to już obszerna objętościowo książka, licząca 160 stron tekstu, który uzupełniały i wzbogacały ilustracje. Zob. M. Jasińska, Alkoholizm. Bibliografia, T. 1, od XVI w. do 1969 r., Warszawa 1993, s. 55.

${ }^{34}$ Nakładem Związku Księży Abstynentów dla Galicji i Bukowiny ukazały się drukiem jeszcze dwie broszurki. Pierwsza z nich to Mały podarek grunwaldzki (1910), zawierająca m.in. 10 nauk przeciw rozpijaniu dzieci. Druga broszurka ukazała się w 1912 r. i informowała o ustawach szynkarskich. Jej nakład oszacować można na 2000 egzemplarzy. Zob. J. Makłowicz, O Związku Księży Abstynentów w Galicji, „Świt”, 91 (1911) s. 144; Sprawozdanie z III-go Walnego Zjazdu galicyjskiego Związu Księży Abstynentów we Lwowie, „Świt”, 106 (1912) s. 195.

${ }^{35}$ Inicjatorem powołania do istnienia towarzystwa „Powściągliwość i Praca” oraz ukazującego się pod tą samą nazwą periodyku był ks. Bronisław Markiewicz (1842-1912), wykładowca teologii 
Stanisław Trojan. Dziełko dedykował autor „Ukochanej Braci abstynenckiej”. Książeczkę poprzedza motto, które najlepiej oddaje jej treść:

„Praca nad swym sercem -

to największy znój!

Walka - z sobą samym -

to najcięższy bój!

Palmę więc zwycięstwa -

ten otrzyma w niebie,

Kto zwyciężać umiał -

wciąż - samego siebie"36!

Publikacja stanowi wybór dwunastu wierszy ${ }^{37}$ autorstwa ks. J. Janiszewskiego, tematycznie związanych z alkoholizmem i walką z tym nałogiem. Celem lepszego zrozumienia, pod niektórymi utworami, znajdują się autorskie adnotacje w formie uwag. Obok dwunastu utworów wierszowanych, w książeczce znalazła się na poły wierszowana Odezwa do ludu polskiego. Potencjalnych czytelników Odezwy autor zachęcał, aby żyli w zgodzie z Bogiem, bliźnim i własnym sumieniem, propagowali oszczędność oraz gospodarność, a w chwilach wolnych od zajęć domowych, czy pracy zawodowej, czytali książki i prasę. Przede wszystkim jednak nie spożywali napojów alkoholowych, a wówczas:

„Ojciec niebieski otrze łzy twoje

I ześlę na cię łask Swoich zdroje!

Szczęście do twojej zawita chaty

I będziesz, ludu, wtedy bogaty!

Bogaty w cnoty, sławę i mienie!

Przyspieszysz wtedy - Polski zbawienie" ${ }^{38 !}$

W marcu 1913 r. ukończył ks. J. Janiszewski pracę nad kolejną książką, której tytuł stanowią przekształcone słowa pochodzące z Ewangelii według św. Łukasza „I ty czyń także!” (Łuk. 10, 37) ${ }^{39}$, a motto poprzedzające treść stanowią słowa św. Augustyna „Mogli ci, czemuż nie ty?” Publikacja ukazała się w Poznaniu w 1913 r., nakładem Związku Księży Abstynentów na archidiecezję gnieźnieńską i poznańską, i liczyła 48 stron. Zrąb główny poprzedzała dedykacja: „Ukochanej Braci abstynenckiej, celem zagrzania Jej do tym gorętszego ukochania idei absty-

pastoralnej, działacz abstynencki i założyciel zakładów wychowawczych dla opuszczonej młodzieży w Miejscu (niedaleko Krosna), które później sam nazwał Miejscem Piastowym. Zob. M.P. Romaniuk, Stuga Boży ksiądz Bronisław Markiewicz (1842-1912), w: W trosce o trzeźwość Narodu, [t. 2], s. 225, 228.

${ }^{36}$ J. Janiszewski, Do walki bracia!, Lwów [1912], s. 4.

${ }^{37}$ I. Nałogowy pijak i - flaszka wódki!; II. Kto rozumniejszy?; III. Nędza i upodlenie - skutki pijaństwa!; IV. Koniec pijaka czyli Jakie życie - taka śmierć!; V. Co ty na to, ojcze, który pijesz? (Rozmowa między dzieckiem a matka); VI. Modlitwa nawróconego pijaka; VII. Pragnę!; VIII. Szczęście i błogosławieństwo Boże - owoce trzeźwości!; IX. Ballada, jakich - mało. (Osnuta na tle prawdziwego zdarzenia); X. Do walki, bracia!; XI. Do broni, bracia!; XII. Przykazania narodowe.

${ }^{38}$ Janiszewski, Do walki, s. 26.

${ }^{39}$ W Ewangelii wg św. Łukasza w przypowieści o Miłosiernym Samarytaninie czytamy: „Idź, i ty czyń podobnie!” 
nenckiej i szerzenia tejże idei zawsze i wszędzie słowem i przykładem, i wszystkim Braciom Rodakom nie abstynentom, celem zachęcenia Ich do zapoznania się z kwestią alkoholizmu i wstąpienia w szeregi abstynenckie"40.

Dziełko rozpoczyna słowo wstępne zatytułowane Dlaczego abstynenci nie piją? Alkohol - zdaniem ks. J. Janiszewskiego - przede wszystkim niszczy zdrowie i prowadzi do licznych schorzeń m.in.: żołądka, serca, wątroby, płuc, nerek, chorób umysłowych. Kolejnym powodem, dla którego warto być abstynentem według autora, stanowi kwestia materialna, abstynent: ,[...] nie traci ani grosza [...], gdy tymczasem nie abstynenci w samej Galicji wydają [na szkodliwe trunki] rocznie 240 milionów koron" ${ }^{41}$. Następnym powodem do zachowania wstrzemięźliwości od alkoholu, jest szczęście rodzinne oraz szacunek i poważanie u innych osób, gdyż abstynent: ,[...] honoru swego nie plami czynami nierozumnymi, jak to często [...] czynią zwolennicy trunków"42. I wreszcie na koniec zwraca się do Polaków, którym przyszło żyć w trudnych czasach niewoli, aby propagowali abstynencję od alkoholu, gdyż to on stanowił jedną z przyczyn utraty niepodległości ${ }^{43}$.

W drugiej części broszury zatytułowanej Znani i znakomici abstynenci nakreślił ks. J. Janiszewski sylwetki 35 abstynentów oraz omówił ich dokonania na tej niwie. Poszczególne biogramy kończą tzw. złote myśli (creda) na temat abstynencji, charakterystyczne dla danych postaci. Część drugą dziełka rozpoczyna biogram św. Jana Chrzciciela, a kończy Zofii Daszyńskiej-Golińskiej4.

Swoistego rodzaju podsumowaniem książeczki ks. J. Janiszewskiego, są jego słowa zawarte w końcowej części: „Jeżeli wśród znanych abstynentów byli i są tacy, co dla dania dobrego przykładu bliźnim lub dla innego mniej ważnego powodu [...] zostali abstynentami, to czyż Ty, Polaku - Katoliku, którego hasłem: «Bóg i Ojczyzna» miałbyś się wahać z wstąpieniem w szeregi abstynenckie, kiedy Bóg, nieszczęśliwa Twoja Ojczyzna i Twój własny dobrze zrozumiany interes do tego Cię wzywają! Patrz! Z pomroku wieków wychyla się ku Tobie postać świetlana wielkiego Augustyna i woła: «Mogli ci i te [...], czemuż byś Ty być nie mógł?» A więc: «I Ty czyń także»"45!

${ }^{40}$ J. Janiszewski, I ty czyń także! (Euk. 10, 37), Poznań 1913, s. 2.

${ }^{41}$ Tamże, s. 4.

${ }^{42}$ Tamże, s. 5.

${ }^{43}$ Tamże, s. 6-7.

${ }^{44}$ W kolejności przedstawia autor: św. Jana Chrzciciela, św. Jadwigę, bł. Salomeę, św. Kazimierza, papieża Grzegorza XVI, kard. Henry Manninga, bpa Augustyna Eggera, o. Teobalda Mathew, ks. Karola Chinigni, króla Szwecji Karola XII, Benjamina Franklina, Daniela O Connell, Abrahama Lincolna, Wilhelma Henryka Harrisona, Wodorowa Wilsona, króla Hiszpanii Alfonsa XIII, cesarza austriackiego Ferdynanda I Habsburga, króla Włoch Wiktora Emanuela III, króla Szwecji i wielkiego księcia Finlandii Gustawa IV Adolfa, króla Prus Wilhelma II Hohenzollerna, Petera Wieselgrena, Mary Hunt, Thomasa Edisona, księcia Mikołaja Radziwiłła, ks. Stanisława Staszica, ks. Karola Antoniewicza, gen. Zygmunta Sierakowskiego, Marię Konopnicką, ks. Bronisława Markiewicza, ks. Jana Beyzyma, Józefa Chociszewskiego, Benedykta Dybowskiego, Wincentego Lutosławskiego, ks. Kazimierza Niesiołowskiego i Zofię Daszyńską-Golińską.

${ }^{45}$ Janiszewski, I ty czyń, s. 46. 


\section{Druki ulotne}

Oprócz książek i broszur, nakładem Związku Księży Abstynentów ukazało się wiele tzw. drobniejszych wydawnictw, czyli najogólniej mówiąc, druków ulotnych. Należały do nich m.in.: obrazki kolędowe i komunijne, widokówki, odezwy, ulotki, tablice poglądowo-statystyczne ${ }^{46}$ oraz ryciny. Wydawnictwa tego typu były najczęściej rozdawane podczas wizyt duszpasterskich, misji, rekolekcji, czy odpustów. Popularyzowały ideę wstrzemięźliwości wśród ogółu społeczeństwa, a zwłaszcza prostego ludu. Zdarzało się jednak, że druki ulotne były sprzedawane. Przykładowo w latach 1905-1906 Związek Księży Abstynentów na archidiecezję gnieźnieńską i poznańską sprzedał przeszło 50000 sztuk różnych ulotek i obrazków. Natomiast w latach 1912-1914 Związek Księży Abstynentów dla Galicji i Bukowiny sprzedał 8500 obrazków, widokówek i ulotek. Nie wiadomo jednak, czy liczba ta odnosi się do wydawnictw własnych Związku, czy ogólnie literatury abstynenckiej, która wówczas wydawana była nakładem wielu abstynenckich organizacji i towarzystw. W literaturę tego rodzaju zaopatrzona bowiem była mieszcząca się we Lwowie składnica abstynencka Związku, gdzie można było zapoznać się z odpowiednimi publikacjami antyalkoholowymi ${ }^{47}$.

Wśród ulotek warto wymienić następujące: Nie dawajcie dzieciom wina, piwa, ani wódki (Wydawnictwo Związku Księży Abstynentów na archidiecezję gnieźnieńską i poznańską) ${ }^{48}$, Co powinni wszyscy wiedzieć o alkoholu?, Dziesięć zdań o alkoholu, Ratuj swa duszę i Precz z przekleństwem (Wydawnictwa Związku Księży Abstynentów dla Galicji i Bukowiny). Swoistego rodzaju ulotkami były też wkładki do książeczek do nabożeństwa, które ukazały się nakładem Związku Księży Abstynentów dla Galicji i Bukowiny. Najprawdopodobniej ok. 1910-1911 r. opublikowane zostały dwa tego typu druki: Owoce wstrzemięźliwości i pijaństwa oraz Pieśń o gorzałce autorstwa Władysława Ludwika Anczyca ${ }^{49}$.

Należy wspomnieć ponadto o sześciu odmianach obrazków kolędowych, z zachęcającą do wstrzemięźliwości modlitwą odpustową, zatwierdzoną przez papieża Piusa X dnia 29 marca 1904 r. Za 100 sztuk tych obrazków, rozdawanych zazwyczaj wiernym podczas składanych im wizyt duszpasterskich, należało na terenie Wielkopolski i Pomorza zapłacić 80 fenigów. Wydaniem obrazków zajął się

${ }^{46}$ Tablice poglądowo-statystyczne wydane nakładem Związku Księży Abstynentów dla Galicji i Bukowiny: Co powinni wszyscy wiedzieć o alkoholu; Wymowne liczby; Zbawienne skutki. Tablice poglądowo-statystyczne wydane nakładem Związku Księży Abstynentów na archidiecezję gnieźnieńską i poznańską opracował ks. Maksymilian Mrugas. Ogółem 44 tablice podzielone na 7 serii: I seria: Alkohol i napoje alkoholowe; II seria: Wplyw alkoholu na zdrowie i życie ludzkie; III seria: Alkohol a praca i sprawność umystowa; IV seria: Alkohol przyczyna zwyrodnienia; V seria: Stosunek alkoholu do przestępstw i zbrodni; VI seria: Walka z alkoholizmem i jej owoce; VII seria: Alkohol w życiu robotnika. A. Egger, Duchowieństwo, (okładka).

${ }^{47}$ Niesiołowski, Związek Księży Abstynentów, s. 14; Ciemniewski, Związek Księży Abstynentów, s. 20, 34; Z. Hałuniewicz, Sprawozdanie z 10-lecia Związku Księży Abstynentów, w: Z okazji dziesięciolecia Związku Księży Abstynentów (1907-1917). Książka zbiorowa, Lwów 1917, s. 10.

${ }^{48}$ [M.] Mrugas, Sprawozdanie sekretarza „Zwiazku Księży Abstynentów” za rok 1909, „Miesięcznik dla Popierania Ruchu Wstrzemięźliwości”, 76 (1910) s. 52.

${ }^{49}$ Makłowicz, O Związku Księży, s. 144. 
Związek Księży Abstynentów na archidiecezję gnieźnieńską i poznańską, diecezję chełmińską, a ponadto Związek Księży Abstynentów dla Galicji i Bukowiny. Drukowano je zazwyczaj w drukarni Buszkiewicza w Toruniu ${ }^{50}$.

Szacuje się, że do 1908 r. Związek Księży Abstynentów dla Galicji i Bukowiny wydał 20 różnego typu drobnych druków, których łączny nakład wyniósł ok. 44000 egzemplarzy ${ }^{51}$.

Zachowane źródła nie pozwalają niestety określić wielkości nakładów druków ulotnych, wydanych przez Związek Księży Abstynentów na archidiecezję gnieźnieńską i poznańską oraz diecezję chełmińską.

\section{Czasopisma}

O konieczności wydawania i czytania prasy abstynenckiej na łamach miesięcznika „Świt” w 1911 r. napisano: „,...] czasopisma, a nie dzieła, czy broszury dają świadectwo o stanie rzeczy w obecnej chwili, o sile idei, jej rozszerzaniu się i zwycięstwach, one podnoszą ducha i zaznajamiają nas ze zdobyczami idei abstynenckiej jako czynnikiem odradzającym i podnoszącym żywotność i sprawność duchową jednostek i narodów, krzepią serce" 52 !

Związek Księży Abstynentów na archidiecezję gnieźnieńską i poznańską był do 1914 roku wydawca kilku periodyków: „Miesięcznik dla Popierania Ruchu Wstrzemięźliwości”, „Świt”, „Przyjaciel Trzeźwości” oraz „Wiadomości z Ruchu Wstrzemięźliwości”. Natomiast oddział w diecezji chełmińskiej pełnił pieczę nad pisemkiem przeznaczonym dla dziecięcych bractw abstynenckich: „Nasz Przewodnik". Pisemko to, ukazujące się w latach 1913-1920 nie było jednak wydawane nakładem Związku Księży Abstynentów, lecz stanowiło inicjatywę jego założyciela i redaktora, ks. Henryka Antoniego Szumana ${ }^{53}$, aktywnego działacza Związku. W stopce redakcyjnej występuje bowiem ks. H.A. Szuman również jako wydawca „Naszego Przewodnika”54.

${ }^{50}$ C., Ruch ekonomiczno-społeczny. Z walki przeciw alkoholizmowi, „Ruch Chrześcijańsko -Społeczny”, 18 (1907) s. 489; N., Walne zebranie Związku Księży Abstynentów w Pelplinie dnia 28-go kwietnia 1910 r., „Miesięcznik dla Popierania Ruchu Wstrzemięźliwości”, 78 (1910) s. 79; O. Śpikowski, Walne Zebranie Zwiazku księży abstynentów, „Świt”, 101 (1912) s. 84; I. Krasińska, „Łatwiej zapobiec chorobie, niż ją wyleczyć”. Bractwa Dzieciątka Jezus i Zwiąki Anioła Stróża dziecięce kótka abstynenckie na ziemiach polskich w latach 1912-1914, w: Virginibus puerisque, t. 2, Z zagadnień wychowania i opieki nad dzieckiem w XVIII-XX wieku, red. E. Kula, M. Pękowska, Kielce 2012, s. 149.

${ }^{51}$ J. Makłowicz, Sprawozdanie „Związu Księży Abstynentów na Galicję” za czas: od założenia Związu do końca 1908 roku, „Gazeta Kościelna”, 4 (1909) s. 44.

${ }^{52}$ Program kót Alumnów - abstynentów polskich. Odczyt, wygłoszony w styczniu b.r. na zebraniu Koła Alumnów - abstynentów seminarium duchownego ob.[rzadku] tac.[ińskiego] we Lwowie, „Świt”, 87 (1911) s. 38.

${ }^{53}$ Henryk Antoni Szuman (1882-1939) - kapłan katolicki, działacz oświatowy, społeczny i abstynencki, redaktor i wydawca. W 1918 r. założył Pomorskie Towarzystwo Opieki nad Dziećmi, a w 1920 r. „Sierociniec im. gen. Hallera”. Zorganizował i wspierał finansowo pierwsze w Polsce kolonie dla dzieci nad morzem. Zob. H. Mross, Szuman Henryk Antoni, SPTK, t. 7, red. L. Grzebień, Warszawa 1983, s. 246.

${ }^{54} \mathrm{O}$ „Naszym Przewodniku” zob. szerzej: W. Theiss, Ks. Henryk Szuman - redaktor „Naszego Przewodnika" (1913-1919), w: Myślenie i działanie pedagoga. Opracowanie dedykowane prof. zw. 
Z inicjatywy ks. Kazimierza Niesiołowskiego, zapoczątkowano wydawanie periodyku: „Miesięcznik dla Popierania Ruchu Wstrzemięźliwości”. Stosowną uchwałę w sprawie wydawania tego pisma podjął Związek Księży Abstynentów 18 września 1903 roku $^{55}$. Okazowy numer wyszedł 1 grudnia 1903 r., lecz faktycznie periodyk ten zaczął ukazywać się dopiero od 1 stycznia 1904 r. Miesięcznik był początkowo organem Związku Księży Abstynentów, ale od 1907 r. reprezentował również interesy świeckiego Towarzystwa Zupełnej Wstrzemięźliwości od Napojów Alkoholowych „Wyzwolenie”. Redaktorem pisma był ks. K. Niesiołowski, a redakcja znajdowała się w Pleszewie, gdzie od 1901 r. pełnił funkcję proboszcza $^{56}$.

Zachęcając do prenumeraty redakcja pisała: „Pismo nasze informować będzie czytelników o wszystkim, co się odnosi do sprawy [tzw.] alkoholizmu"s7. I dalej: „Prosimy nie szczędzić sił i zabiegów, bo sprawa walki z alkoholizmem obchodzi cały naród. [„Miesięcznik dla Popierania Ruchu Wstrzemięźliwości”] jest jedynym tego rodzaju pismem na wszystkie trzy zabory. Mimo tego nie zdoła się utrzymać, jeżeli ci, którzy mają zrozumienie rzeczy, nie poprą pisma naszego ze wszystkich sif"s8.

Po takim apelu odzew musiał być spory, skoro już w 1905 r. periodyk prenumerowało 300 osób, a w dwa lata później odnotowano już przeszło 800 abonentów ${ }^{59}$. Dział ekspedycji i drukarnia znajdowały się w Pleszewie, w zakładach graficznych F.K. Ziółkowskiego i Sp.

W 1908 r. Józef Kostrzewski, ${ }^{60}$ późniejszy wybitny archeolog, rozpoczął w Poznaniu redagowanie i wydawanie miesięcznika "Swit” skierowanego do polskiej młodzieży abstynenckiej. Jak sam wspominał, periodyk ten redagował

dr hab. Zdzisławowi Kosyrzowi z okazji 50-lecia pracy naukowej, red. M. Konopczyński, J. Kunikowski, S. Tomiuk, Warszawa 2009, s. 73-86; I. Krasińska, Działalność redakcyjno-wydawnicza ks. Henryka Antoniego Szumana na rzecz najmłodszych odbiorców. Na przykładzie „,Naszego Przewodnika" (1913-1919), w: Działalność instytucji wydawniczych na rzecz oświaty i edukacji w XIX i początkach XX wieku, red. I. Michalska, G. Michalski, Łódź 2014, s. 299-318.

${ }^{55}$ Niektóre opracowania wskazują, że wydawcą „Miesięcznika dla Popierania Ruchu Wstrzemięźliwości”, a od 1911 r. „Świtu” był ks. Kazimierz Niesiołowski, gdyż zarówno w winiecie, jak i w stopce redakcyjnej nie podano wydawcy, a widnieje tylko redaktor. Zob. Polskie czasopisma religijno-społeczne w XIX wieku, red. B. Lesisz [i in.], Warszawa-Lublin 1988, s. 362.

${ }^{56}$ Niesiołowski, Związek Księży Abstynentów, s. 13; Gulczyński, Ks. prałat Kazimierz Niesiotowski, s. 39.

${ }^{57}$ [K. Niesiołowski], Zaproszenie do przedpłaty, „Miesięcznik dla Popierania Ruchu Wstrzemięźliwości” 1903, nr na okaz, s.b.p.

${ }^{58}$ [K. Niesiołowski], Zaproszenie do przedpłaty, „Miesięcznik dla Popierania Ruchu Wstrzemięźliwości”, 1 (1904) s.b.p.

${ }^{59}$ Mrugas, Sprawozdanie ze zebrania, s. 68; Niesiołowski, Zwiazek Księży Abstynentów, s. 14.

${ }^{60}$ Józef Kostrzewski (1885-1969) - muzeolog i archeolog, początkowo studiował medycynę we Wrocławiu, potem zainteresował się archeologią. W 1919 r. (po habilitacji) objął katedrę prehistorii na Uniwersytecie w Poznaniu. Z ruchem abstynenckim zetknął się w czasach gimnazjalnych. W okresie międzywojennym pomimo pracy naukowej i badawczej, działał m.in. w Polskiej Lidze Przeciwalkoholowej. Zob. Z. Jaroszewski, Prof. dr Józef Kostrzewski, „Problemy Alkoholizmu”, 3-4 (1966) s. 25-27. 
przez trzy lata (1908-1910): „W piśmie tym, które rozchodziło się we wszystkich zaborach i które firmował jako redaktor Jan Całka, (bo w ówczesnych stosunkach politycznych, jako student medycyny uniwersytetu wrocławskiego, jawnie jako redaktor występować nie mogłem), propagowaliśmy poza abstynencją, m.in. urządzanie przez młodzież gimnazjalną wycieczek pieszych dla lepszego poznania kraju, bliższego zetknięcia się z ludem i wyrobienia w sobie tężyzny fizycznej i moralnej" ${ }^{61}$.

Redakcja miesięcznika mieściła się początkowo w Poznaniu przy ul. Strzeleckiej 25, a następnie ul. Fabrycznej 35b. Za druk pisma odpowiedzialna była Drukarnia i Księgarnia św. Wojciecha. Pismo składało się z sześciu działów: Artykuly zasadnicze, $Z$ dziejów ruchu wstrzemięźliwości i z literatury, Artykuły sprawozdawcze, referaty itd., Artykuly o kwestiach bieżacych i różne, Korespondencje oraz Drobne wiadomości. Pismo utrzymywało się głównie z opłat abonamentowych i prywatnych datków, o czym redakcja pisała zamieszczając nazwiska darczyńców i kwoty jakie ofiarowali na rzecz periodyku: „Byt i rozwój jedynego dziś pisemka abstynenckiego młodzieży polskiej zależy od Was koledzy. Tylko wasze poparcie umożliwi nam stworzenie ze „Świtu” prawdziwego organu polskiej młodzieży abstynenckiej, który będzie omawiał wszystkie sprawy, interesujące tę część młodzieży, która drogą własnego odrodzenia wewnętrznego dąży do odrodzenia narodu" ${ }^{\prime} 2$.

Z uwagi na fakt, że J. Kostrzewskiemu trudno było dłużej redagować „Świt”, ze względu na podjęcie studiów w Londynie oraz kłopoty finansowe, zaproponował ks. K. Niesiołowskiemu połączenie go z „Miesięcznikiem dla Popierania Ruchu Wstrzemięźliwości”. Do scalenia pism doszło najpewniej również dlatego, że ,[...] jedno i drugie przeznaczone dla inteligentów, równe [miały] cele", a więc z roku na rok zmniejszać się musiała liczba ich prenumeratorów. Propozycja złożona przez J. Kostrzewskiego, została przez ks. K. Niesiołowskiego zaakceptowana, i od 1 stycznia 1911 r. wychodził „Świt” - miesięcznik dla popierania ruchu wstrzemięźliwości. Redaktorem został ks. K. Niesiołowski. Odtąd pismo było organem nie tylko Związku Księży Abstynentów i Towarzystwa Zupełnej Wstrzemięźliwości od Napojów Alkoholowych „Wyzwolenie”, lecz reprezentował również interesy polskiej młodzieży abstynenckiej ${ }^{63}$.

W numerze styczniowym z 1911 r. przeczytać można: „[...] ufamy, że czytelnicy dotychczasowego organu młodzieży nie odmówią swego poparcia złączonemu pismu. Tak bowiem, jak w ubiegłych rocznikach Miesięcznika zwracaliśmy się do młodzieży polskiej, tak i nadal silnie podkreślać będziemy znaczenie młodzieży w wszelakiej pracy nad podniesieniem i odrodzeniem narodu. Jeżeli rzuciliśmy przed 10 laty hasło wyrzeczenia się trucizny, która nas poniża i osłabia, to wiedzieliśmy dobrze, że hasło nie zostałoby nigdy w czyn zamienione bez udziału młodzieży, bez jej płomiennego zapału" ${ }^{\prime 4}$.

${ }^{61}$ Tamże, s. 26.

${ }^{62}$ Od Redakcji, Ś"wit”, 6-7 (1909) s. 66.

${ }^{63}$ M. Mrugas, Sprawozdanie ze zebrania Zwiazku Księży Abstynentów odbytego dnia 24-go listopada 1910 we , Wyzwoleniu” na św. Łazarzu, „Miesięcznik dla Popierania Ruchu Wstrzemięźliwości”, 85 (1910) s. 194; Gulczyński, Ks. prałat Kazimierz Niesiołowski, s. 44; Jaroszewski, Prof. dr Józef Kostrzewski, s. 26.

${ }^{64}$ N., U progu Nowego Roku, „Świt”, 86 (1911) s. 1-2. 
Redakcja „Świtu” mieściła się w Pleszewie, lecz pismo drukowane było w Poznaniu w drukarni „Praca” przy ul. Rycerskiej 38. Abonament można było wykupić we wszystkich urzędach pocztowych na terenie Niemiec i Austro-Węgier, oraz w składnicy abstynenckiej, mieszczącej się przy ul. Św. Marcin 69.

Od stycznia 1912 r. zmianie uległ podtytuł periodyku na miesięcznik poświęcony walce $\mathrm{z}$ alkoholizmem. Po połączeniu obu pism zwiększyła się objętość pojedynczego numeru z 16 do 24 stron. Miesięcznik miał układ działowy z przewagą następujących: Artykuły, Korespondencje, Wiadomości ze świata, Ziemie polskie, Rozmaitości, Wiadomości związkowe Wyzwolenia, Związek Księży Abstynentów, Wiadomości z Towarzystw, Z piśmiennictwa. W 1912 r. nakład pisma wynosił 1000 egzemplarzy, a liczbę prenumeratorów oszacować można na 740. Połączenie obu periodyków nie okazało się zatem korzystne. Nie przybyło nowych czytelników, wielu dotychczasowych nie opłacało na czas opłaty abonamentowej, więc skreślono ich z listy prenumeratorów. W celu zwiększenia liczby abonentów, przez rok numer okazowy „Świtu” rozsyłany był bezpłatnie do wszystkich księży z archidiecezji gnieźnieńskiej i poznańskiej oraz diecezji chełmińskiej. Nie przyniosło to jednak spodziewanych rezultatów. Znacznie wzrosły natomiast, z uwagi na zwiększoną objętość numeru, koszty druku' ${ }^{65}$.

W 1910 r. Związek Księży Abstynentów przystąpił do wydawania miesięcznika „Wiadomości z Ruchu Wstrzemięźliwości”. Pisemko to zawierało krótkie wzmianki, dotyczące kwestii alkoholizmu. Rozsyłane było raz na miesiąc do przeszło 200 polskich gazet ${ }^{66},[\ldots]$, które sprawę wstrzemięźliwości jeszcze rzadko poruszają, a odebrawszy materiał już gotowy do druku z pewnością chętniej i częściej czynić to będą"67. Redakcja miesięcznika w numerze pierwszym z 1910 r. apelowała do redakcji pism polskich: ,[...], aby zechciały łaskawie korzystać z tego urządzenia i umieszczać w miarę możności nadsyłane im wiadomości, które - czytane przez szerokie masy ludności - w znacznie większym stopniu przyczynią się do uświadomienia społeczeństwa w tej ważnej kwestii narodowej i społecznej, niż artykuły pism abstynenckich, ograniczonych do szczupłego koła czytelników, którzy zresztą przeważnie już z kwestią alkoholizmu są obeznani. Mamy nadzieję, że Szan.[owone] Redakcje nie odmówią nam swego poparcia w tej ważnej sprawie wytrzeźwienia ludu naszego i dopomogą wydawnictwu naszemu do spełnienia jego zadania" $" 68$.

Liczba odbiorców „Wiadomości z Ruchu Wstrzemięźliwości” nie była duża, biorąc pod uwagę fakt, że każde polskie pismo, mogło na żądanie otrzymywać ten periodyk bezpłatnie. Dla indywidualnych odbiorców roczny abonament wynosił 1 markę. Pomimo niewielkiej objętości pojedynczego numeru (4 strony tekstu),

${ }^{65}$ Niesiołowski, Związek Księży Abstynentów, s. 17; Śpikowski, Związek Księży Abstynentów, s. 99; tenże, Walne zebranie, s. 84; Gulczyński, Ks. prałat Kazimierz Niesiołowski, s. 44.

${ }^{66}$ Niesiołowski, Związek Księży Abstynentów, s. 14.

${ }^{67}$ M. Mrugas, Sprawozdanie ze zebrania „Zwiazku księży Abstynentów” odbytego dnia 18-go listopada 1909, w „, Gospodzie wstrzemięźliwości” przy Dominikanach w Poznaniu, „Miesięcznik dla Popierania Ruchu Wstrzemięźliwości”, 73 (1909) s. 192.

${ }^{68}$ Redakcja ,Wiad.[omości] z ruchu wstrzem.[ięźliwości], Do Szanownych Redakcji Pism polskich w zaborze pruskim!, „Wiadomości z Ruchu Wstrzemięźliwości”, 1 (1910) s. 1. 
koszty druku tego miesięcznika wyniosły 200 marek $^{69}$. Pisemko ukazywało się tylko dwa lata (1910-1911). W pierwszym roku jego redaktorem był J. Kostrzewski. Redakcja znajdowała się wówczas w Ostrowie przy ul. Kaliskiej 21. Od stycznia 1911 r. funkcję redaktora objął ks. Onufry Śpikowski ${ }^{70}$, pracujący wówczas jako wikary w parafii w Wilczynie, tak więc redakcja pisma przeniesiona została do tej miejscowości. Od połowy 1911 r. mieściła się w Otorowie. Administracja periodyku posiadała swoją siedzibę w Poznaniu przy sekretariacie (składnicy) Związku Księży Abstynentów. Za druk odpowiadała początkowo Drukarnia i Księgarnia św. Wojciecha w Poznaniu, ale od numeru trzeciego (1910 r.) drukiem periodyku zajmowała się drukarnia „Praca”.

W styczniu 1907 r. ukazał się w Bytomiu pierwszy numer publikowanego nakładem tamtejszego Wydawnictwa „Katolik” pisma zatytułowanego „Przyjaciel Trzeźwości”. Był to miesięcznik poświęcony sprawom krzewienia trzeźwości i zwalczania alkoholizmu. W zamierzeniu twórców: „Pismo [miało] zająć się systematycznie sprawą trzeźwości i nieść oświatę potrzebną, aby nasz lud zwycięsko stoczył walkę z jednym z największych wrogów swoich, z alkoholizmem"71. Redaktorami miesięcznika byli kolejno: Bronisław Ruczyński, Paweł Dombek ${ }^{72}$ i Józef Bednorz.

Pismo cieszyło się dużą popularnością, zwłaszcza wśród członków Towarzystwa Zupełnej Wstrzemięźliwości od Napojów Alkoholowych „Wyzwolenie”. W 1909 r. prenumerowało go 1200 osób: ,[...], ale redagowane przez nie abstynenta i bardzo nieregularnie dostawiane" powodowało niezadowolenie i liczne skargi ze strony prenumeratorów. Podczas zebrania Związku Księży Abstynentów na archidiecezję gnieźnieńską i poznańską, odbytego 18 listopada 1909 r., na wniosek prezesa, ks. K. Niesiołowskiego, zadecydowano, aby od 1 stycznia 1910 r. Związek przejął nakład „Przyjaciela Trzeźwości”. W numerze dwunastym w grudniu 1909 r. dotychczasowy wydawca poinformował o tym czytelników i prenumeratorów ${ }^{73}$.

Począwszy od stycznia 1910 roku „Przyjaciel Trzeźwości” ukazywał się więc nakładem Związku Księży Abstynentów, a jego redaktorem został ks. Maksymilian Mrugas $^{74}$. Wraz ze zmianą wydawcy i redakcji zmienił się podtytuł periodyku

${ }^{69}$ Śpikowski, Walne Zebranie Zwiazku, s. 84.

${ }^{70}$ Onufry Antoni Śpikowski (1884-1943) - kapłan katolicki, działacz społeczno-oświatowy, członek Poznańskiego Towarzystwa Przyjaciół Nauk. Podczas wojny polsko-bolszewickiej (1920 r.) był kapelanem Wojska Polskiego. W młodości udzielał się w ruchu abstynenckim. Zob. L. Wilczyński, Śpikowski Onufry Antoni, w: Księża społecznicy w Wielkopolsce 1894-1919. Słownik biograficzny, t. 4, (Ś-Ż), red. L. Wilczyński, H. Szatkowski, Gniezno 2009, s. 27.

${ }^{71}$ Redakcja „Przyjaciela Trzeźwości”, Niech będzie pochwalony Jezus Chrystus!, „Przyjaciel Trzeźwości”, 1 (1907) s. 1-2.

${ }^{72}$ Paweł Dombek (1865-1925) - górnośląski działacz społeczny i oświatowy, dziennikarz, polityk. Był gorliwym katolikiem i dobrym mówcą. Odznaczał się dużą wiedzą z zakresu prawodawstwa. Zob. W. Ogrodziński, Dombek Pawet, PSB, t. 5, Kraków 1946, s. 312.

${ }^{73}$ Mrugas, Sprawozdanie ze zebrania, s. 192; Rozmaitości, „Przyjaciel Trzeźwości”, 12 (1909) S. 192.

${ }^{74}$ Maksymilian Mrugas (1878-1957) - kapłan katolicki, działacz abstynencki i społeczny. Współpracował ze Związkiem Księży Abstynentów, jak również działał aktywnie w świeckim 
i odtąd pismo ukazywało się jako miesięcznik dla szerzenia wstrzemięźliwości między ludem. Jak zaznaczono, było to najtańsze pismo przeznaczone dla bractw i towarzystw wstrzemię́liwości. Redakcja miesięcznika znajdowała się najpierw w Poznaniu przy Nowym Rynku 16, a od lipca 1911 roku w Głuszynie. Ekspedycją zajmowała się drukarnia „Praca” oraz sekretariat, a następnie składnica abstynencka Związku. Pismo w miarę regularnie ukazywało się do końca 1914 r. Jego układ miał charakter działowy: Wiadomości z Towarzystw, Artykuły, Obrazki z życia, Wiadomości ze świata, Wiadomości z ziem polskich, Ofiary alkoholizmu, Rozmaitości, Wesoly kacik, Wiersze, Zdania stawnych ludzi swoich i obcych.

W numerze pierwszym w styczniu 1910 r. redakcja napisała: „Oto przed Wami pierwszy numer czwartego rocznika. Stary «Przyjaciel Trzeźwości» tylko w nową suknię przybrany, aby oko [...] z przyjemnością na nim spocząć mogło. Ale serce w nim bije to samo. Jedno je tylko pragnienie ożywia: służyć dobrej sprawie, pracować dla dobra ludu polskiego, aby było między nim więcej miłości - więcej dobrobytu, więcej szczęścia w rodzinach, mniej grzechów [...]. Więc przygotujcie i uprawcie tę rolę serc Waszych na przyjęcie zbożnego ziarna [...]. Witajcie go u progu chaty jako dobrego przyjaciela. Im dłużej obcować będziecie z tym «Przyjacielem Trzeźwości» tym bardziej go pokochacie, bo on Wam przyniesie zajmującą naukę, da dobrą radę i wskazówki dla Waszego, dzieci Waszych i bliźnich Waszych dobra i uszczęśliwienia"75.

Dzięki nowemu redaktorowi i wydawcy, wzrosła dość znacznie, popularność „Przyjaciela Trzeźwości”, który już w końcu 1910 r. doczekał się przeszło 4000 prenumeratorów. Dwa lata później było ich już 4500. Najwięcej stałych czytelników wywodziło się z Poznania, z dzielnicy Święty Łazarz (450), z Inowrocławia (400) i Połajewa (200). „Przyjaciel Trzeźwości” pomimo swej monotematyczności, był przez ks. M. Mrugasa redagowany w zajmujący i żywy sposób. Poza przystępnie napisanymi artykułami, czy wzmiankami z towarzystw abstynenckich, zawierał także żartobliwe powiastki, wierszyki oraz tzw. Wesoły kacik, gdzie znaleźć można było szereg dowcipów. Zdaniem ks. Onufrego Śpikowskiego stałych prenumeratorów mogło być znacznie więcej, gdyby wzrosło zainteresowanie tym pismem wśród członków Towarzystwa Zupełnej Wstrzemięźliwości od Napojów Alkoholowych "Wyzwolenie" przebywających na emigracji w Westfalii. Większą popularność zdobył sobie wśród nich krakowski miesięcznik „Iskra” (1910-1914), poświęcony sprawie wychowania narodowego i poczwórnej wstrzemię́liwości (od alkoholu, tytoniu, rozpusty i hazardu) ${ }^{76}$.

\footnotetext{
Towarzystwa Zupełnej Wstrzemięźliwości od Napojów Alkoholowych „Wyzwolenie”. W czasie Powstania Wielkopolskiego włączył się w prace niepodległościowe. Zob. H. Szatkowski, Mrugas Maksymilian, w: Księża społecznicy w Wielkopolsce 1894-1919. Słownik biograficzny, t. 2, (I- O), [red. L. Wilczyński, H. Szatkowski], Gniezno 2007, s. 318-319.

${ }^{75}$ Redakcja „Przyjaciela Trzeźwości”, Do naszych Czytelników, „Przyjaciel Trzeźwości”, 1 (1910) s. 3-4.

${ }^{76}$ Śpikowski, Walne Zebranie Związu, s. 84; tenże, Związek Księży Abstynentów, s. 99; Niesiołowski, Związek Księży Abstynentów, s. 16; Szatkowski, Mrugas Maksymilian, s. 318.
} 


\section{Podsumowanie}

Rozpowszechnianiem wydawnictw własnych Związku Księży Abstynentów zajmowały się składnice abstynenckie działające w Poznaniu i Lwowie. Z inicjatywy ks. K. Niesiołowskiego w 1907 r. założono sekretariat Związku, przekształcony w 1910 r. w składnicę abstynencką, mieszczącą się w Poznaniu przy ul. Św. Marcin 69. Natomiast we Lwowie nadzór nad składnicą mieli przygotowujący się do kapłaństwa klerycy - abstynenci, a swoją siedzibę składnica posiadała $\mathrm{w}$ gmachu tamtejszego seminarium duchownego. Składnice zaopatrzone były nie tylko w wydawnictwa Związku Księży Abstynentów, ale również w najważniejsze książki, broszury, druki ulotne, prasę abstynencką i inne publikacje, wydawane przez wiodące polskie oraz zagraniczne organizacje i towarzystwa abstynenckie. O działalności i znaczeniu składnic abstynenckich najlepiej świadczy fakt, że w latach 1912-1914 lwowska składnica sprzedała 1800 broszur i 8500 widokówek, druków ulotnych oraz obrazków kolędowych i komunijnych. W składnicy poznańskiej można było natomiast złożyć zamówienie i dokonać przedpłaty na wydawane nakładem Związku Księży Abstynentów wydawnictwa periodyczne.

słowa kluczowe: Związek Księży Abstynentów, ks. Kazimierz Niesiołowski, alkoholizm, abstynencja

\section{PUBLISHING ACTIVITY OF THE ASSOCIATION OF TEETOTAL PRIESTS} (1903-1914)

\section{Summary}

One of the aims of the Association of Teetotal Priests was to combat alcoholism by publishing relevant literature addressed to a wide audience. The first publications released by the Association appeared in 1903. The Association of Teetotal Priests published six books (brochures and books of small size) to the outbreak of the First World War. Moreover, there were dozens types of ephemeral prints, among which worth mentioning are: carol and communion pictures, postcards, appeals, pictorial and statistical charts, graphs and inserts for prayer books. Another thing worth noting is the fact that the Association of Teetotal Priests in the Archdiocese of Gniezno and Poznań also published periodicals.

A number of priests from the Association were engaged in scientific, journalistic and editorial activity. Among them special mention should be drawn to: Rev. Kazimierz Niesiołowski, Rev. Józef Janiszewski, Rev. Henryk Antoni Szuman, Rev. Maksymilian Mrugas and Rev. Onufry Śpikowski.

The publications of the Association were distributed mainly by the abstinence secretariats (depots) located in Poznań and Lviv. It is noteworthy that those members of the Association who paid regular fees received all publications free of charge.

Kewords: the Association of Teetotal Priests, Rev. Kazimierz Niesiołowski, alcoholism, abstinence 